
143 Medical Center : Institute of Life Sciencos. Hobrew Universlty and Dept. of Urology. Share Zedek Medical Center. Jerusalem. Israel. IN VITRO METABOLIC STUDIES OF TESTICULAR TISSUE IN
FAMILIAL MALE PSEUDOHERMAPHRODITISM DUE TO 17-KETOREDUCTASE DEFICIENCY.

Kinetic analyses of progesterone and androstenedione metabolism were performed in testicular tissue of 5 male pseudohormaphrodites (MPH) with familial 17-kotoreductuse deficiency previously described (J. Steroid Blochem.. 19:663-674, 1983), and compared to 2 normal controls. The age of the pationts ranged between 3-3/4 and 35 years. Testicular tissue vas obtained during surgery lor male genitoplasty in 4 cases, and duriog castration in one individual, who had been reared unequivocally as a female. White the testicular tissue of the 2 prepubertal MPH metabolized prosesterone to androstenedione only. and tissue of the 2 prepubertal MPH metabolized prosesterone to androstenedione only. and
that in a limited extent, the 3 postpubertal MPH metubolized progesterone to $160-$ and that in a limited extent, the 3 postpubertal MPH metubolized progesterone to $160 \alpha$ - and
16 -hydroxyprogesterone (16-0HP). 17-hydroxyprogesterone, androstenedione and to testosterone. These MPH motabolized androstenedione to testosterone as well. to a comparable extent as the controls. The Michaelis constant of these reactions was similar for the MPH and the controls. An 7.8 to 12.8-fold increase in the production of 16-OHP, and a 4.6 to 11.5 -fold inhibition of the 17-hydroxylase was found in the testes of the MPH The preference of androstened lone production by the testes of 2 MPH was examined using a equitar the flow of substrates in the normal testes was equal or slightly preferable through the $\Delta-A$ pathway, a more than 8 -times preterence of the $\Delta-5$ pathway vas noted in the testes of the MPH. A large accumulation of DHEA was found upon orission of NAD, the 3B-steroid dehydrogenase-isomerase cofactor. supporting the contention that in MPH androstenedione is mainly produced through the $\Delta-5$ pathway. Further support for this was the finding that the $3 \mathrm{H} / 14 \mathrm{C}$ ratio of androstenedione and testosterone produced Irom both substrates vas 8-times higher in MPH than in controls. MPH due to 17-ketoreductase deficiency appears to be a mixture of complex metabolic aberrations in the androgen biosynthetic pathway.

A. Otten* J. Kreuder* , Zachmann, H.U. Schweikert* Tntrod. by M. Zachmann)

14.4 Departments of Pediatrics, Universities of Giessen and Zurich and Department of Medicine, University of Bonn, FRG and Switzerland

17,20-DESMOLASE DEFICIENCY IN A 8 MONTH OLD INFANT

During an uneventful pregnancy, prenatal sex determination of the fetus was performed on parental request. A $46, X Y$ karyotype was
found. At term, a phenotypic girl was born, and a second chromosome analysis confirmed the $46, X Y$ constitution. There was a complete vagina, but on echography, gonads and uterus could not be pleen with certainty. At age 8 months. FSH was $53 \mu \mathrm{U} / \mathrm{mol}$. LH $3 \mu \mathrm{U} / \mathrm{l}$ seen with certainty. At age 8 months, FSH was $53 \mu \mathrm{U} / \mathrm{mol}$, LH $3 \mu \mathrm{U} / \mathrm{A}$ IU $/ \mathrm{m}^{2}$ ) there was no increment of testosterone. Urinary steroids $\mathrm{IU} / \mathrm{m}^{2}$ ), there was no increment of testosterone. Ur inary steroids
before arid after hCG and ACTH (gas chromatography on capillary before and after hCG and ACTH (gas chromatography on capillary cortisol (total of THE, THF, alloTHF, cortolone, B-cortolone 1.95 $\mu \mathrm{mol} / \mathrm{d}$ ) and progesterone metabolites (pregnanediol 0.14 , pregnanetriol $0.2 \mu \mathrm{mol} / \mathrm{d}$ ) were normal, but individual 17-ketosteroids (androsterone 0.42, etiochol anolone 0.14 ) low or undectable (DHEA). Thus, inspite of the common cytochrome P450, 17d-hydroxylating activity was normal. Urinary $5 \beta / 5 \alpha$ ratio was normal $(0.33)$. In fibroblasts cultured from biopsy at labium majora androgen receptor binding was just below normal, but surprisingly the $5 \alpha$-reductase activity reduced $(0.60 \mathrm{pmol} / \mathrm{mg}$ protein
normal $>1)$. This reduction appears to be secondary to the lack normal $>1)$. This reduction appears to be secondary
of the substrate testosterone during embryogenesis.

Supported by Swiss National Science Fcundation Grant No. 3.874.83 und DFG Schw 168/5-8.

\footnotetext{
J.E. Toublanc, N. Abbas*, M. Toublanc*, N.A. Af fara* M. Fellous ${ }^{\star}$ J.C. Job

145 Hôpital Saint-Vincent-de-Paul, U 276 INSERM, Institut Pasteur, Paris, France ; Dept of Pathology, University of Cambridge, U.K. ANALYSIS OF XX MALES AND XX TRUE HERMAPHRODITES, ARGUMENTS FOR A NON-Y TESTICULAR DETERMINING GENE. 9 patients having testicular tissue with $46, \mathrm{XX}$ karyotype, aged 9 patients having testicular tissue with $46, \mathrm{Xx}$ karyotype, aged
month to 16 years and followed through puberty, were studied. month to 16 years and followed through puberty, were studied.
According to their phenotype they were $246, \mathrm{XX}$ males with normal male phenotype and 7 with abnormal external genitalia (AG), among whom 4 with hypospadias and 3 with true hermaphroditism (TH). Th endocrine data were identical in the three groups: testosterone normal during puberty, then decreased in adulthood, gonadotrop in levels being already above the control values at mid-puberty. Biopsies were identical in the 2 subgroups of AC patients up years: no difference with controls, regardless of the ovarian part of the ovotestis ; after 8 years, germ cells disappeared dysgenesis became obvious. In one patient, the ovarian zone of the gonad appeared only after complete serial cuts of the gonad removed. Southern analysis of Y-DNA sequences displayed the presence of $Y$-specific material in $46, x X$ classical males and the lack of the sequence in all patients with $A G$.

These findings, together with the knowlegde of familial cases of $\mathrm{XX}$ males with $\mathrm{AG}$ and $\mathrm{TH}$ allow to consider that $\mathrm{XX}$ males with $\mathrm{AC}$ and $\mathrm{TH}$ are the alternative expression of the same genetic defect and that a non-Y testis determining factor might be active in these patients in place of the testis determinants usually present on the $Y$ chromosome, or on the $X$ chromosome in $X X$ classical males.
}

\section{S. Stillman ${ }^{\star}$, B.A.J. Evans ${ }^{*}$, I.A. Hughes.}

146

Department of Child Health, University of Wales College of Medicine, Cardiff, UK.

PERIPHERAL AROMATASE ACTIVITY IN ANDROGEN INSENSITIVITY SYNDROMES.

Basal and androgen-stimulated aromatase activity was studied in genital sk in fibroblasts (GSF) from normals $(n=18)$ and patients with androgen insensitivity syndrome (AIS; $n=8$ ). Enzyme activity was determined f fom the release of [ $\left[{ }^{3}\right] \mathrm{H}_{2} \mathrm{O}$ following the conversion of $\left[1 \mathrm{~B}-\mathrm{H}_{\mathrm{H}}\right]$ androstenedione $([1 \mathrm{~B}-3 \mathrm{H}]-\mathrm{A})$ to oestrone. Using a substrate concentration 2-50 $\mathrm{nM}$, saturation kinetic analysis yielded a Vmax (maximum velocity) of $184 \pm 104$ $\mathrm{fmol} / \mathrm{mg}$ protein $/ \mathrm{hr}$ (mean \pm SD) and a $\mathrm{kM}$ (Michaelis-Menten constant) of $6.9 \pm 2 \mathrm{nM}$ in normal GSF strains, and values of 186 \pm 9.1 (Vmax) and $8.5 \pm 2.6(\mathrm{kM})$, respectively in AIS strains. Androgens increased aromatase activity in normal GSF strains. Androgens increased aromatase activity in normal GSF strains.
Pre-incubation with $10 \mathrm{~mm}$ mibolerone (a synthetic androgen) for $48 \mathrm{hr}$ produced a 4.2 - 38 fold increase in basal aromatase activity. The response in receptor-positive $(n=5)$ and receptor-deficient $(n=2)$ partial AIS strains was $12.4-23.5$ and $1.1-2.4$ fold, respectively. There was no stimulaton of aromatase in a receptor-negative complete AIS strain. The results provide evidence of a permissive role for androgens in the control of peripheral aromatase activity. The effect is androgen receptor mediated based on studies of GSF strains from AIS patients with a dysfunctional receptor, and may provide an

additional in vitro qualitative marker of androgen
responsiveness. 